\title{
MedChemComm
}

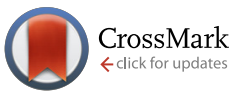

Cite this: Med. Chem. Commun., 2016, 7, 1003

Received 12th January 2016, Accepted 12th March 2016

DOI: $10.1039 / c 6 m d 00023 a$

www.rsc.org/medchemcomm

\section{Synthesis of radioiodinated probes to evaluate the biodistribution of a potent TRPC3 inhibitort:}

\author{
Masayori Hagimori, ${ }^{a}$ Takahiro Murakami, ${ }^{a}$ Kinue Shimizu, ${ }^{b}$ Motohiro Nishida, bc \\ Takashi Ohshimab and Takahiro Mukai*a
}

\begin{abstract}
The transient receptor potential canonical 3 (TRPC3) channel is a member of the TRPC family that contributes to the entry of $\mathrm{Ca}^{2+}$ through the plasma membrane or modulates the driving force for $\mathrm{Ca}^{2+}$ entry channels. The pyrazole compound Pyr3 has recently been reported to be a selective TRPC3 inhibitor and has become an attractive research tool and therapeutic agent for the treatment of heart failure. However, the in vivo characteristics of Pyr3 have not been investigated. To monitor the fate of Pyr3 in vivo, we designed and synthesized a radioiodinated Pyr3 probe ([125 I]I-Pyr3) by introducing radioiodine at the 2-position of the central phenyl ring of Pyr3. I-Pyr3 was shown to have direct TRPC3 inhibition activity similar to that of Pyr3 in TRPC3-overexpressing HEK293 cells. Using the tributyltin derivative as a radioiodination precursor, $\left[{ }^{125} \mid\right] l-P y r 3$ was successfully prepared with high radiochemical purity. Biodistribution studies of $\left[{ }^{125} \mid\right]$ I-Pyr3 and $\left[{ }^{125} \mid\right] \mid-P y r 8$ (the esterolysis product of $\left[{ }^{125} \mid\right] \mid-P y r 3$ ) indicated high uptake of intact $\left[{ }^{125} \mid\right] \mid-P y r 3$ in the lung and rapid metabolism to $\left[{ }^{125} \mathrm{l}\right] \mathrm{I}-\mathrm{Pyr} 8$. These findings provide useful information about the in vivo kinetics of the selective TRPC inhibitor Pyr3.
\end{abstract}

\section{Introduction}

Changes in the intracellular concentration of the calcium ion $\left(\left[\mathrm{Ca}^{2+}\right]_{\mathrm{i}}\right)$ modulate a wide range of cellular processes, including secretion, gene expression, proliferation, and cell death. ${ }^{1-4}$ Although $\left[\mathrm{Ca}^{2+}\right]_{\mathrm{i}}$ is normally maintained in the $10-$ $100 \mathrm{nM}$ range, it is increased by the release of $\mathrm{Ca}^{2+}$ from intracellular stores and the endoplasmic reticulum (ER) on activation. In addition, $\left[\mathrm{Ca}^{2+}\right]_{\mathrm{i}}$ is increased by the influx of $\mathrm{Ca}^{2+}$ across the plasma membrane in response to extracellular stimulation. ${ }^{5}$ Abnormal changes in $\left[\mathrm{Ca}^{2+}\right]_{\mathrm{i}}$ influence intracellular $\mathrm{Ca}^{2+}$ homeostasis and can cause diseases. ${ }^{5}$

The transient receptor potential canonical (TRPC) channel is a subfamily of TRP channels and contributes to changes in $\left[\mathrm{Ca}^{2+}\right]_{\mathrm{i}}$ by serving as a $\mathrm{Ca}^{2+}$ entry pathway in the plasma membrane or by modulating the driving force for $\mathrm{Ca}^{2+}$ entry chan-

\footnotetext{
${ }^{a}$ Kobe Pharmaceutical University, 4-19-1 Motoyamakita Machi, Higashinada-ku, Kobe 658-8558, Japan. E-mail: tmukai@kobepharma-u.ac.jp; Fax: +8178 4417541; Tel: +81784417539

${ }^{b}$ Graduate School of Pharmaceutical Sciences, Kyushu University, 3-1-1 Maidashi, Higashi-ku, Fukuoka 812-8582, Japan

${ }^{c}$ Okazaki Institute for Integrative Bioscience (National Institute for Physiological Sciences), National Institutes of Natural Sciences, 5-1 Higashiyama, Okazaki, Aichi 444-8787, Japan

$\dagger$ The authors declare no competing interests.

\$ Electronic supplementary information (ESI) available. See DOI: 10.1039/ c6md00023a
}

nels. ${ }^{6}$ It has been reported that TPRC channels are closely related to heart diseases, including cardiac hypertrophy and fibrosis, and cancer. ${ }^{7-10}$ TRPC channels can be divided into seven isoforms (TRPC1-TRPC7), and TRPC1 and TRPC3-7 are broadly expressed in mammals. ${ }^{11,12}$ TRPC channels are activated in response to membrane receptors linked to phospholipase C (PLC), including PLC $\beta$ and PLC $\gamma$. TRPC3, TRPC6, and TRPC7 are directly activated by PLC-derived diacylglycerol (DAG). ${ }^{6}$

To elucidate the functions of a TRPC channel, several small molecules, such as SKF 96365, LOE908, and 2-APB, have been evaluated as TRP inhibitors. ${ }^{13,14}$ However, the roles played by the TRPC channels have not been adequately characterized because these inhibitors exhibit low selectivity toward TRPC channels. BTP2 has been reported to be a TRPC channel inhibitor that does not influence mitochondrial $\mathrm{Ca}^{2+}$ signaling, ER $\mathrm{Ca}^{2+}$ release, or $\mathrm{K}^{+}$channels in T-cells. However, BTP2 lacks TRPC subtype selectivity. ${ }^{15-17}$ The pyrazole compound Pyr3 has been recently reported to be a selective TRPC3 inhibitor that directly inhibits the TRPC3 channel by binding to its extracellular side. ${ }^{18}$ Pyr3 regulated the TRPC3-mediated $\mathrm{Ca}^{2+}$ influx in $\mathrm{B}$ lymphocytes and eliminated the $\mathrm{B}$ cell receptor-induced $\mathrm{Ca}^{2+}$ oscillation. Pyr3 also inhibited pressure overload-induced cardiac hypertrophy in mice with transverse aortic constriction. ${ }^{18}$ Furthermore, in an in vitro model of stent-induced arterial injury, Pyr3 prevented arterial injury by suppressing agonist-induced $\mathrm{Ca}^{2+}$ entry into vascular smooth muscles. $^{19}$ 
These findings suggest that Pyr3 could be used as a research tool and a therapeutic agent for the treatment of heart failure. Nevertheless, little is known about the in vivo characteristics of Pyr3, including its distribution, metabolism, and elimination. In addition, because the ester moiety of Pyr3 is easily hydrolyzed, Pyr3 is converted to Pyr8, the carboxylic acid derivative, which shows little TRPC3 inhibition. Radiolabeled probes are widely used to study the in vivo characteristics of drugs. Iodine radioisotopes $\left({ }^{123} \mathrm{I},{ }^{125} \mathrm{I}\right.$, and $\left.{ }^{131} \mathrm{I}\right)$ have higher specific activities than $\beta$-emitters, such as ${ }^{3} \mathrm{H}$ or ${ }^{14} \mathrm{C}$, and are commonly used in biological assay and in vivo imaging. ${ }^{125}$ I has a relatively long half-life and emits low energy photons, thus the pyrazole compounds were labeled with ${ }^{125}$ I. In this study, we synthesized the radiolabeled probes $\left(\left[{ }^{125} \mathrm{I}\right] \mathrm{I}-\mathrm{Pyr} 3\right.$ and $\left.\left[{ }^{125} \mathrm{I}\right] \mathrm{I}-\mathrm{Pyr} 8\right)$ (Fig. 1) and used them to monitor the fate of Pyr3 in vivo.

\section{Results and discussion}

\subsection{Chemistry}

Pyr3 comprises two structural motifs: an ethyl-3trifluoromethylpyrazole-4-carboxylate group and a trichloroacrylic amide group. The trichloroacrylic amide group of Pyr3 is critical for the observed TRPC3-selective inhibition. ${ }^{18}$ The effect of introducing a functional group to the central phenyl ring of Pyr3 on TRPC3 channel inhibition or selectivity has not been reported. We designed ethyl 1-(2-[ ${ }^{125}$ I] iodo-4-(2,3,3-trichloroacrylamido)phenyl)-5(trifluoromethyl)-1 $\mathrm{H}$-pyrazole-4-carboxylate, $\left[{ }^{125} \mathrm{I}\right] \mathrm{I}-\mathrm{Pyr} 3$, to introduce radioiodine at the 2-position of the central phenyl ring of Pyr3. Nonradioactive I-Pyr3 was synthesized via the route outlined in Scheme 1. Reaction of 2-bromo-1-fluoro-4nitrobenzene with hydrazine hydrate, followed by treatment with ethyl 2-(ethoxymethylene)-4,4,4-trifluoro-3-oxobutyrate, afforded the pyrazole derivative 3 in $94 \%$ yield. Treatment of 3 with zinc dust and aqueous $\mathrm{NH}_{4} \mathrm{Cl}$ afforded the amine 4 in 95\% yield. A bromo to tributyltin exchange reaction using $\mathrm{Pd}\left(\mathrm{PPh}_{3}\right)_{4}$ and a subsequent iododestannylation reaction yielded the iodine derivative 6. I-Pyr3 was prepared from 6 in $60 \%$ yield by treatment with 2,3,3-trichloroacryloyl chloride. Alkaline hydrolysis of the ester moiety of I-Pyr3 afforded the carboxylic acid derivative, I-Pyr8, in $18 \%$ yield.

\subsection{Measurement of intracellular $\mathrm{Ca}^{2+}$ concentration}

The ability of Pyr derivatives to inhibit TRPC3-mediated $\mathrm{Ca}^{2+}$ influx in vitro was evaluated using TRPC3-overexpressing

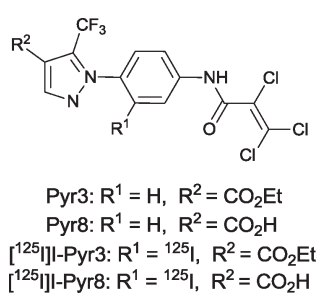

Fig. 1 Structure of TRPC3-targeted compounds.

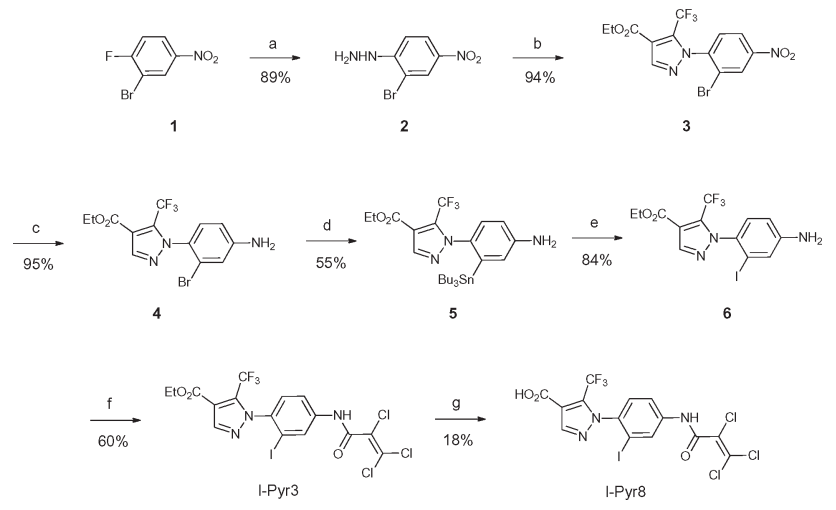

Scheme 1 Syntheses of I-Pyr3 and I-Pyr8. Reagents and conditions: (a) $\mathrm{NH}_{2} \mathrm{NH}_{2} \cdot \mathrm{H}_{2} \mathrm{O}, \mathrm{EtOH}$, reflux, $2 \mathrm{~h}$, (b) ethyl 2-(ethoxymethylene)4,4,4-trifluoro-3-oxobutyrate, $\mathrm{H}_{2} \mathrm{SO}_{4}$, EtOH, reflux, $4 \mathrm{~h}$, (c) zinc dust, aqueous $\mathrm{NH}_{4} \mathrm{Cl}$ solution, EtOAc, $0{ }^{\circ} \mathrm{C}, 4 \mathrm{~h}$, (d) $\mathrm{Pd}\left(\mathrm{PPh}_{3}\right)_{4}, \mathrm{SnBu}_{3}$, toluene, $60{ }^{\circ} \mathrm{C}, 15 \mathrm{~h}$, (e) $\mathrm{I}_{2}, \mathrm{CH}_{2} \mathrm{Cl}_{2}, \mathrm{rt}, 2.5 \mathrm{~h}$, (f) 2,3,3-trichloroacryloyl chloride, $\mathrm{CH}_{2} \mathrm{Cl}_{2}, \mathrm{~N}, \mathrm{~N}$-diisopropylethylamine, $0{ }^{\circ} \mathrm{C}, 1 \mathrm{~h}$, and (g) $1 \mathrm{M}$ $\mathrm{KOH}$ (aq.), $\mathrm{EtOH}, \mathrm{H}_{2} \mathrm{O}, \mathrm{rt}, 8 \mathrm{~h}$.

HEK293 cells (Fig. 2). I-Pyr3 showed potent inhibition of the TRPC3 channel-mediated $\mathrm{Ca}^{2+}$ influx that was only slightly poorer than that of the mother compound (Pyr3). ${ }^{18}$ This result suggested that the introduction of iodine at the 2-position of the central phenyl ring of Pyr3 did not affect its ability to inhibit the TRPC3-mediated $\mathrm{Ca}^{2+}$ influx and that ${ }^{125} \mathrm{I}$-labeled I-Pyr3 could be a promising probe to monitor the fate of Pyr3 in plasma.

\subsection{Radiosynthesis}

The radioiodinated analog $\left[{ }^{125} \mathrm{I}\right] \mathrm{I}-\mathrm{Pyr} 3$ was obtained via the iododestannylation of tributyltin precursor 7, which was obtained from the reaction of amine 5 with 2,3,3-

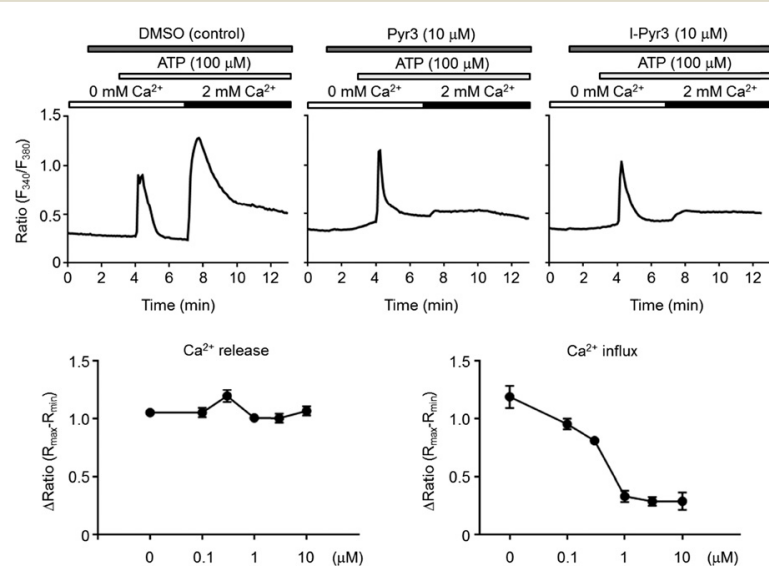

Fig. 2 Concentration-dependent inhibition of TRPC3-mediated $\mathrm{Ca}^{2+}$ influx by I-Pyr3. Upper panels: average changes in intracellular $\mathrm{Ca}^{2+}$ concentration $\left(\left[\mathrm{Ca}^{2+}\right]_{\mathrm{i}}\right)$ induced by endogenous purinergic receptor stimulation in TRPC3-overexpressing HEK293 cells ( $n=45-92$ cells) in the presence or absence of extracellular $\mathrm{Ca}^{2+}(2 \mathrm{mM})$. The cells were treated with Pyr3 2 min prior to ATP stimulation. Lower panels: concentration-dependent inhibition of TRPC3-mediated $\mathrm{Ca}^{2+}$ influx by I-Pyr3. 
<smiles>CCOC(=O)c1cnn(-c2ccc(N)cc2)c1C(F)(F)F</smiles>
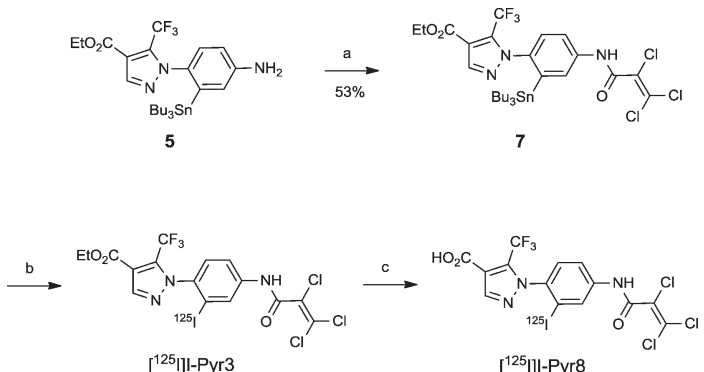

$\left[{ }^{125} \mid\right]-P y r 3$ $\left[{ }^{125} \mid\right] \mid-P y r 8$

Scheme 2 Syntheses of $\left[{ }^{125} \mid\right] \mid-P y r 3$ and $\left[{ }^{125} \mid\right] \mid-P y r 8$. Reagents and conditions: (a) 2,3,3-trichloroacryloyl chloride, $\mathrm{CH}_{2} \mathrm{Cl}_{2}$, DIEPA, $0{ }^{\circ} \mathrm{C}, 1 \mathrm{~h}$, (b) chloramine-T, $\mathrm{AcOH}, \mathrm{MeOH},\left[{ }^{125} \mathrm{l}\right] \mathrm{Nal}, 35{ }^{\circ} \mathrm{C}, 2 \mathrm{~h}$, and (c) $1 \mathrm{M} \mathrm{KOH}$ (aq.), EtOH, $\mathrm{H}_{2} \mathrm{O}, \mathrm{rt}, 8 \mathrm{~h}$.

(a)

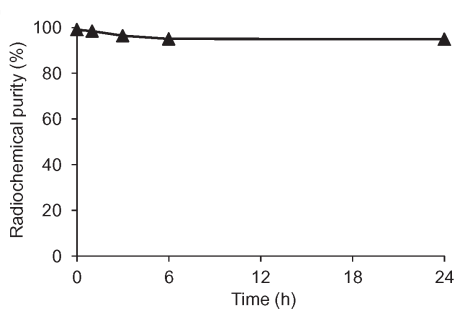

(b)

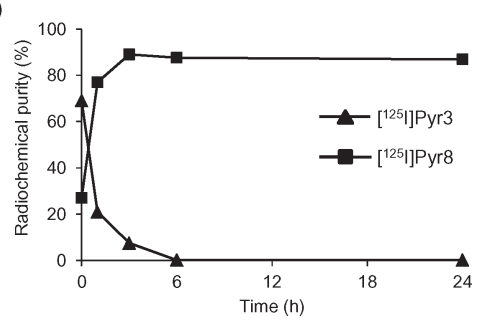

Fig. 3 Stability studies of (a) $\left[{ }^{125} \mid\right] l-P y r 3$ in $20 \mathrm{mM}$ phosphate buffer $(\mathrm{pH} 7.4)$ and (b) $\left[{ }^{125} \mathrm{I}\right] \mathrm{I}-\mathrm{Pyr} 3$ in mouse plasma.

trichloroacryloyl chloride. However, its radiochemical yield was only $15 \%$ when $\mathrm{N}$-chlorosuccinimide was used as an oxidant. After the optimization of reaction conditions, the radiochemical yield of $\left[{ }^{125} \mathrm{I}\right] \mathrm{I}-\mathrm{Pyr} 3$ improved to $39 \%$ when chloramine-T was used as an oxidant (Scheme 2). The carbox- ylate analog $\left[{ }^{125} \mathrm{I}\right] \mathrm{I}-\mathrm{Pyr} 8$ was also obtained in high yield $(84 \%)$ via the alkaline hydrolysis of the ester moiety of $\left[{ }^{125} \mathrm{I}\right] \mathrm{I}-\mathrm{Pyr} 3$. The radiochemical purities and specific activities of these $\left[{ }^{125} \mathrm{I}\right] \mathrm{I}$-labeled compounds were greater than $98 \%$ and greater than $26.3 \mathrm{GBq} \mu \mathrm{mol}^{-1}$, respectively.

\subsection{Stability studies}

The in vitro stability of $\left[{ }^{125} \mathrm{I}\right] \mathrm{I}-\mathrm{Pyr} 3$ in $20 \mathrm{mM}$ phosphate buffer (PB; pH 7.4) or mouse plasma at $37{ }^{\circ} \mathrm{C}$ was evaluated using radio-TLC analysis (Fig. 3). The radioactivity of $\left[{ }^{125} \mathrm{I}\right] \mathrm{I}-\mathrm{Pyr} 3$ remained $>95 \%$ intact for $24 \mathrm{~h}$ in $\mathrm{PB}$, while the radioactivity of $\left[{ }^{125} \mathrm{I}\right] \mathrm{I}$-Pyr3 rapidly decreased and completely disappeared after $6 \mathrm{~h}$ in mouse plasma. The metabolite of $\left[{ }^{125} \mathrm{I}\right] \mathrm{I}-\mathrm{Pyr} 3$ was identified as $\left[{ }^{125} \mathrm{I}\right] \mathrm{I}-\mathrm{Pyr}$, indicating the rapid hydrolysis of the ester group of $\left[{ }^{125} \mathrm{I}\right] \mathrm{I}-\mathrm{Pyr} 3$.

\subsection{In vivo biodistribution in normal mice}

To characterize the in vivo kinetics of Pyr3, a biodistribution study of $\left[{ }^{125} \mathrm{I}\right] \mathrm{I}-\mathrm{Pyr} 3$ was carried out in normal ddY mice (Table 1). The radioactivity of $\left[{ }^{125} \mathrm{I}\right] \mathrm{I}$-Pyr3 cleared rapidly from the blood pool and showed considerable accumulation in the lung, small intestine, and liver $10 \mathrm{~min}$ after injection. In addition, accumulation of radioactivity was broadly observed in the stomach, heart, kidney, and muscle. The thyroid accumulation was low, indicating high stability against in vivo deiodination. Because $\left[{ }^{125} \mathrm{I}\right] \mathrm{I}$-Pyr3 was hydrolysed to $\left[{ }^{125} \mathrm{I}\right] \mathrm{I}$ Pyr8, the distribution of radioactivity after administration of $\left[{ }^{125} \mathrm{I}\right] \mathrm{I}-\mathrm{Pyr} 3$ might reflect the distribution of $\left[{ }^{125} \mathrm{I}\right] \mathrm{I}-\mathrm{Pyr} 8$. Therefore, we performed a biodistribution study of $\left[{ }^{125} \mathrm{I}\right] \mathrm{I}-\mathrm{Pyr} 8$ (Table 2). Similar to $\left[{ }^{125} \mathrm{I}\right] \mathrm{I}-\mathrm{Pyr} 3,\left[{ }^{125} \mathrm{I}\right] \mathrm{I}-\mathrm{Pyr} 8$ showed rapid blood clearance and considerable accumulation of radioactivity in the small intestine and liver. However, the lung radioactivity after administration of $\left[{ }^{125} \mathrm{I}\right] \mathrm{I}$-Pyr8 was dramatically lower compared to that after $\left[{ }^{125} \mathrm{I}\right] \mathrm{I}$-Pyr3 administration. These results indicated that $\left[{ }^{125} \mathrm{I}\right] \mathrm{I}-\mathrm{Pyr} 3$ is broadly distributed, especially to the lung, as an intact form at early times post-injection, and that this is followed by rapid metabolism to $\left[{ }^{125} \mathrm{I}\right] \mathrm{I}$-Pyr8.

Table 1 Biodistribution in normal mice after iv injection of $\left[{ }^{125} \mathrm{I}\right] \mathrm{I}-\mathrm{Pyr} 3^{a}$

\begin{tabular}{|c|c|c|c|c|c|}
\hline Organ & $10 \mathrm{~min}$ & $30 \mathrm{~min}$ & $1 \mathrm{~h}$ & $3 \mathrm{~h}$ & $24 \mathrm{~h}$ \\
\hline Spleen & $1.52 \pm 0.21$ & $1.02 \pm 0.17$ & $0.93 \pm 0.08$ & $0.98 \pm 0.14$ & $0.98 \pm 0.19$ \\
\hline Stomach & $3.14 \pm 2.97$ & $3.42 \pm 2.64$ & $3.27 \pm 2.96$ & $1.47 \pm 1.04$ & $0.07 \pm 0.02$ \\
\hline Intestine & $18.20 \pm 2.25$ & $21.09 \pm 2.28$ & $26.51 \pm 3.75$ & $26.91 \pm 3.72$ & $0.05 \pm 0.01$ \\
\hline Kidney & $3.10 \pm 0.45$ & $1.23 \pm 0.40$ & $0.93 \pm 0.17$ & $0.60 \pm 0.09$ & $0.27 \pm 0.03$ \\
\hline Liver & $14.59 \pm 2.91$ & $6.16 \pm 2.57$ & $7.80 \pm 2.64$ & $4.29 \pm 1.51$ & $0.21 \pm 0.03$ \\
\hline Muscle & $2.24 \pm 0.46$ & $2.66 \pm 0.78$ & $1.92 \pm 0.24$ & $2.02 \pm 0.81$ & $1.29 \pm 0.34$ \\
\hline Brain & $1.11 \pm 0.12$ & $0.94 \pm 0.09$ & $1.04 \pm 0.25$ & $0.57 \pm 0.11$ & $0.23 \pm 0.04$ \\
\hline Thyroid $^{b}$ & $0.13 \pm 0.03$ & $0.14 \pm 0.03$ & $0.16 \pm 0.05$ & $0.19 \pm 0.08$ & $0.29 \pm 0.11$ \\
\hline Urine $^{b}$ & & & & & $3.77 \pm 1.45$ \\
\hline Feces $^{b}$ & & & & & $73.81 \pm 10.52$ \\
\hline
\end{tabular}

${ }^{a}$ Each value represents the mean \pm s.d. $(n=5)$. Expressed as \% injection dose per gram of organ. ${ }^{b}$ Expressed as $\%$ injection dose. 
Table 2 Biodistribution in normal mice after iv injection of $\left[{ }^{125} \mid\right] \mid-P y r 8^{a}$

\begin{tabular}{|c|c|c|c|c|c|}
\hline Organ & $10 \mathrm{~min}$ & $30 \mathrm{~min}$ & $1 \mathrm{~h}$ & $3 \mathrm{~h}$ & $24 \mathrm{~h}$ \\
\hline Blood & $0.64 \pm 0.04$ & $0.46 \pm 0.14$ & $0.36 \pm 0.04$ & $0.31 \pm 0.04$ & $0.28 \pm 0.05$ \\
\hline Spleen & $1.40 \pm 0.71$ & $0.97 \pm 0.18$ & $0.92 \pm 0.23$ & $0.89 \pm 0.11$ & $0.69 \pm 0.17$ \\
\hline Pancreas & $1.75 \pm 1.70$ & $0.64 \pm 0.13$ & $0.54 \pm 0.20$ & $0.88 \pm 0.30$ & $0.60 \pm 0.16$ \\
\hline Stomach & $1.59 \pm 0.46$ & $0.47 \pm 0.25$ & $0.91 \pm 0.13$ & $1.15 \pm 0.41$ & $0.12 \pm 0.04$ \\
\hline Intestine & $18.06 \pm 7.65$ & $22.83 \pm 6.08$ & $27.53 \pm 3.09$ & $21.44 \pm 1.48$ & $0.10 \pm 0.04$ \\
\hline Kidney & $2.34 \pm 0.68$ & $1.03 \pm 0.43$ & $0.83 \pm 0.17$ & $0.85 \pm 0.58$ & $0.23 \pm 0.03$ \\
\hline Liver & $12.22 \pm 2.60$ & $9.37 \pm 1.87$ & $8.94 \pm 6.27$ & $8.08 \pm 2.75$ & $0.12 \pm 0.02$ \\
\hline Heart & $1.00 \pm 0.36$ & $0.84 \pm 0.32$ & $0.75 \pm 0.07$ & $0.64 \pm 0.04$ & $0.63 \pm 0.16$ \\
\hline Lung & $1.31 \pm 1.02$ & $0.76 \pm 0.40$ & $0.59 \pm 0.03$ & $0.57 \pm 0.10$ & $0.45 \pm 0.07$ \\
\hline Muscle & $2.34 \pm 0.78$ & $1.90 \pm 0.85$ & $1.93 \pm 0.83$ & $1.78 \pm 0.99$ & $1.03 \pm 0.35$ \\
\hline Brain & $0.31 \pm 0.07$ & $0.36 \pm 0.06$ & $0.55 \pm 0.49$ & $0.31 \pm 0.04$ & $0.23 \pm 0.05$ \\
\hline Thyroid $^{b}$ & $0.10 \pm 0.02$ & $0.10 \pm 0.01$ & $0.10 \pm 0.01$ & $0.13 \pm 0.02$ & $0.13 \pm 0.03$ \\
\hline Urine $^{b}$ & & & & & $2.50 \pm 0.65$ \\
\hline Feces $^{b}$ & & & & & $77.08 \pm 8.38$ \\
\hline
\end{tabular}

\section{Conclusions}

We successfully designed and synthesized $\left[{ }^{125} \mathrm{I}\right] \mathrm{I}-\mathrm{Pyr} 3$ and $\left[{ }^{125} \mathrm{I}\right] \mathrm{I}-\mathrm{Pyr} 8$ and used these compounds for the in vivo characterization of the selective TRPC3 inhibitor Pyr3. The ability of I-Pyr3 to inhibit TRPC3-mediated $\mathrm{Ca}^{2+}$ influx was comparable to Pyr3. Biodistribution studies of $\left[{ }^{125} \mathrm{I}\right] \mathrm{I}-\mathrm{Pyr} 3$ and $\left[{ }^{125} \mathrm{I}\right] \mathrm{I}-\mathrm{Pyr} 8$ in normal mice showed that $\left[{ }^{125} \mathrm{I}\right] \mathrm{I}-\mathrm{Py} 3 \mathrm{3}$ is highly distributed to the lung as an intact form at early times post-injection and that this is followed by rapid metabolism to $\left[{ }^{125} \mathrm{I}\right] \mathrm{I}-\mathrm{Pyr} 8$. These findings provide useful information about the in vivo kinetics of the selective TRPC inhibitor Pyr3.

\section{References}

1 S. N. Yang and P. O. Berggren, Endocr. Rev., 2006, 27, 621.

2 S. W. Flavell and M. E. Greenberg, Annu. Rev. Neurosci., 2008, 31, 563.

3 J. M. Schmitt, E. Abell, A. Wagner and M. A. Davare, Mol. Cell. Biochem., 2010, 335, 155.

4 S. P. Yu, L. M. Canzoniero and D. W. Choi, Curr. Opin. Cell Biol., 2001, 13, 405.

5 D. E. Clapham, Cell, 2007, 131, 1047.

6 S. F. Pedersen, G. Owsianik and B. Nilius, Cell Calcium, 2005, 38, 233.

7 M. M. El-Mas, H. M. El-Gowelli and M. C. Michel, NaunynSchmiedeberg's Arch. Pharmacol., 2013, 386, 929.

8 Z. Yue, Y. Zhang, J. Xie, J. Jiang and L. Yue, Curr. Top. Med. Chem., 2013, 13, 270.
9 E. Aydar, S. Yeo, M. Djamgoz and C. Palmer, Cancer Cell Int., 2009, 9, 23.

10 S. L. Yang, Q. Cao, K. C. Zhou, Y. J. Feng and Y. Z. Wang, Oncogene, 2009, 28, 1320.

11 A. Riccio, A. D. Medhurst, C. Mattei, R. E. Kelsell, A. R. Calver, A. D. Randall, C. D. Benham and M. N. Pangalos, Mol. Brain Res., 2002, 109, 95.

12 Y. Jang, Y. Lee, S. M. Kim, Y. D. Yang, J. Jung and U. Oh, Arch. Pharmacal Res., 2012, 35, 1823.

13 K. Treiber, A. Singer, B. Henke and W. E. Müller, Br. J. Pharmacol., 2005, 145, 75.

14 J. P. Lievremont, G. S. Bird and J. W. Putney Jr., Mol. Pharmacol., 2005, 68, 758.

15 L. P. He, T. Hewavitharana, J. Soboloff, M. A. Spassova and D. L. Gill, J. Biol. Chem., 2005, 280, 10997.

16 J. Ishikawa, K. Ohga, T. Yoshino, R. Takezawa, A. Ichikawa, H. Kubota and T. Yamada, J. Immunol., 2003, 170, 4441.

17 C. Zitt, B. Strauss, E. C. Schwarz, N. Spaeth, G. Rast, A. Hatzelmann and M. Hoth, J. Biol. Chem., 2004, 279, 12427.

18 S. Kiyonaka, K. Kato, M. Nishida, K. Mio, T. Numaga, Y. Sawaguchi, T. Yoshida, M. Wakamori, E. Mori, T. Numata, M. Ishii, H. Takemoto, A. Ojida, K. Watanabe, A. Uemura, H. Kurose, T. Morii, T. Kobayashi, Y. Sato, C. Sato, I. Hamachi and Y. Mori, Proc. Natl. Acad. Sci. U. S. A., 2009, 106, 5400.

19 S. Koenig, M. Schernthaner, H. Maechler, C. O. Kappe, T. N. Glasnov, G. Hoefler, M. Braune, E. Wittchow and K. Groschner, J. Pharmacol. Exp. Ther., 2013, 344, 33. 